\title{
Energy resources of spermatozoa of the rainbow trout Oncorhynchus mykiss (Pisces, Teleostei)
}

\author{
F Lahnsteiner 1, RA Patzner 1, T Weismann 2 \\ 1 Zoological Institute, University of Salzburg, Hellbrunnerstr, 34, A-5020 Salzburg; \\ ${ }^{2}$ Bundesanstalt für Fischereiwirtschaft, Scharfling 18, A-5310 Mondsee, Austria
}

(Received 19 May 1992; accepted 22 June 1993)

\begin{abstract}
Summary - Spermatozoa of Oncorhynchus mykiss have the enzymatic capacity for glycolysis, for triglyceride and phospholipid catabolism and triglyceride synthesis. They lack glucosidase activity and are therefore not able to utilize polysaccharides as energy resources.

In motile spermatozoa glycolysis occurs during the first $30 \mathrm{~s}$ of motility and - when motility is initiated in a physiological saline solution - triglyceride catabolism is used for the regeneration of ATP levels after motility has ended. When immotile spermatozoa are incubated with the seminal plasma or in physiological saline solution they behave similarly as regards utilization of their primary energy reserves: glycolysis as well as catabolism of triglycerides occurs. In $\approx 60 \%$ of the semen samples, spermatozoa synthesize triglycerides at the onset of incubation. Possible physiological reasons for triglyceride synthesis have been discussed.
\end{abstract}

spermatozoa $/$ Oncorhynchus mykiss $=$ rainbow trout $/$ metabolism $/$ motility $/$ energy resources

Résumé - Ressources énergétiques des spermatozoïdes de la truite arc-en-ciel Oncorhynchus mykiss (Poisson Téléostéen). Les spermatozoïdes dOncorhyncus mykiss, au catabolisme des triglycérides et des phospholipides, ainsi qu'à la synthèse des triglycérides. Par contre, ils sont démunis d'activités glycosidases et sont, par conséquent, incapables d'utiliser les polysaccharides comme source d'énergie. Dans les spermatozoïdes mobiles, la glycolyse se produit au cours des 30 premières secondes de motilité et - lorsque la motilité est initiée dans une solution saline physiologique - le catabolisme des triglycérides est utilisé pour restaurer les niveaux d'ATP après que la motilité a cessé. Quand des spermatozö̈des immobiles sont incubés avec du plasma séminal ou dans une solution saline physiologique, ils se comportent de la même manière quant à l'utilisation de leur réserve primaire d'énergie : il se produit une glycolyse ainsi qu'un catabolisme des triglycérides. Dans environ $60 \%$ des échantillons de sperme, les spermatozoïdes synthétisent des triglycérides au début de l'incubation. Les causes physiologiques possibles d'une synthèse des triglycérides sont discutées. 


\section{INTRODUCTION}

The energy resources of fish spermatozoa have lacked detailed investigations until now. Studies have been performed on $\mathrm{Cy}$ matogaster aggregata; Poecilia sp spermatozoa (Gardiner, 1978) and Oncorhynchus mykiss (Terner and Korsh, 1963a, b). Glycolysis was found to occur in spermatozoa of internally fertilizing fish, while sperm cells of externally fertilizing fish were found to use lipids (Stoss, 1983). Due to the limited amount of data a generalization of this concept is problematical.

In the rainbow trout (Oncorhynchus mykiss) spermatozoa mainly metabolize fatty acids and are capable of glycolysis to only a small extent (Terner and Korsh, 1963a, b). During motility, which in the trout is short and lasts $<1 \mathrm{~min}$, spermatozoa rely mainly on endogenous energy reserves (ATP) which are readily available (Christen et al, 1987). When spermatozoa are shed into fresh water, it is the osmotic shock that ends motility (Billard and Cosson, 1992). However, when motility is initiated in physiological saline solution, ATP levels can be regenerated after motility has ended and motility initiated a second time (Minassian and Terner, 1966; Mounib, 1967; Christen et al, 1987). The primary energy substrates of trout spermatozoa and their definitive utilization during motility and immotile storage have not been examined until now.

Thus, the present study investigates the primary energy metabolism of spermatozoa of the rainbow trout, Oncorhynchus mykiss. It describes the enzyme systems involved in glycolysis and lipid metabolism and determines the energy resources and their changes during immotile storage and during motility of spermatozoa.

\section{MATERIAL AND METHODS}

\section{Collection of semen}

Adulte male Oncorhynchus mykiss (autumn and winter strain) were obtained from fishery farms. Semen was collected by stripping the abdomen of fish in the middle of their spawning season. Special care was taken to avoid contamination with urine and feces. Each fish was stripped only once, whereby 1.5 to $4.5 \mathrm{ml}$ semen were obtained.

\section{General procedure}

Semen quality was controlled by visual parameters (deterioration, consistency) and by motility. To separate the spermatozoa from the seminal plasma, the semen was centrifuged at $350 \mathrm{~g}$ for $10 \mathrm{~min}$ at $4^{\circ} \mathrm{C}$. Sperm cells were washed twice in a motility-inhibiting solution $(103 \mathrm{mM} \mathrm{NaCl}, 40$ $\mathrm{mM} \mathrm{KCl}, 20 \mathrm{mM}$ Hepes, $\mathrm{pH} 7.8$ ) (dilution rate spermatozoa: motility inhibiting solution $=1: 3$ ) and subsequently suspended in the same saline solution at a ratio of 1:3 (spermatozoa: diluent). Spermatocrit of the suspensions was 10 to $15 \%$ and sperm density 10-15 x $10^{9}$ spermatozoa/ml.

For initiation of motility, sperm suspensions were diluted in a motility-activating solution (103 $\mathrm{mM} \mathrm{NaCl}, 20 \mathrm{mM}$ Hepes $\mathrm{pH} 9.5$ ) in a ratio of $1: 15$. Motility was determined at $4^{\circ} \mathrm{C}$ under a microscope by counting the number of spermatozoa passing a distinct area in ratio to the total number of spermatozoa. In all incubation experiments sperm was stored in a 10 - to $15-\mathrm{mm}$ thick layer in reaction vessels with a diameter of 15 $\mathrm{mm}$. Photometric measurements were performed with a Shimadzu UV 160 spectrophotometer.

\section{Determinations of enzyme activities in spermatozoa}

To obtain crude enzyme extracts, spermatozoa were homogenized in appropriate extraction solutions for the subsequent assay procedures, con- 
taining $0.1 \%$ Triton $X-100$ in a tight-fitting Dounce homogenizer. For the extraction of lipid synthase a $0.1-\mathrm{M}$ potassium phosphate buffer with $50 \mathrm{mM}$ 2-mercaptoethanol and $0.1 \%$ Triton $X-100$ was used. Ten min after homogenization the samples were centrifuged at $1000 \mathrm{~g}$ for $15 \mathrm{~min}$ and the clear supernatant containing the crude enzyme preparation was used for assays within $2 \mathrm{~h}$. No protease inhibitors were utilized. All enzyme extraction steps were performed at $+4^{\circ} \mathrm{C}$.

Lipase activity was investigated by the titrimetric method of Junge (Bergmeyer, 1985) with a $25 \%$ suspension of olive oil as substrate (concentration in assay) (incubation time: $3 \mathrm{~h}, 4^{\circ} \mathrm{C}$ ) phospholipase activity by the titrimetric method of Magee and Uthe (Lowenstein, 1981) (incubation: $3 \mathrm{~h}, 20^{\circ} \mathrm{C}$, substrate: $2 \%$ phosphatidylcholine suspension). Alpha-glucosidase (substrate: 56 $\mathrm{mM}$ sucrose) and $\beta$-galactosidase (substrate: $56 \mathrm{mM}$ lactose) activity was investigated via glucose liberation (Dahlqvist; in Bergmeyer, 1985) (incubation time: $2 \mathrm{~h}, 4^{\circ} \mathrm{C}$ ). Determination of lactate dehydrogenase activity was according to the colorimetric method of Deneke (Bergmeyer, 1985) (substrate: $40 \mathrm{mM}$ pyruvate, incubation time: $30 \mathrm{~min}, 4^{\circ} \mathrm{C}$ ). Pyruvate kinase activity was investigated by $\mathrm{NADH}$ oxidation rate with $5 \mathrm{mM}$ phosphoenolpyruvate as substrate (Fujii and Miwa; in Bergmeyer, 1985). Glucose-6phosphate dehydrogenase was measured by UV-spectrophotometry using $3.3 \mathrm{mM}$ glucose-6phosphate as substrate (Deutsch, in Bergmeyer, 1985). Fatty acid synthase was measured by a spectrophotometric assay according to Roncari (Lowenstein, 1981). The assay mixture contained $100 \mathrm{mM}$ potassium phosphate buffer $(\mathrm{pH} 7.0)$, $100 \mathrm{mM}$ NADPH, $0.2 \mathrm{mM}$ EDTA, $25 \mu \mathrm{m}$ acetyl$\mathrm{CoA}$ and $50 \mu \mathrm{M}$ malonyl-CoA.

\section{Determination of metabolite levels in spermatozoa during motility and during immotile storage}

\section{Determination of metabolites during motility}

In spermatozoa suspended in the physiological saline solution, motility was initiated as described with the motility activating solution. Special care was taken to obtain homogeneous suspensions of spermatozoa in the diluents. In a second series of experiments motility was initiat- ed in the same manner, but $10 \mathrm{mM}$ potassium cyanide (final concentration) was added.

Before activation ( $0 \mathrm{~min}$ ), $0.5,1,5,10,15$ and $20 \mathrm{~min}$ after motility was initiated the metabolism of spermatozoa was inactivated in appropriate boiling buffer solution for the subsequent assay procedure, containing $0.1 \%$ Triton $X-100$ (diluted spermatozoa: extraction solution $=1: 4$ ). After $15 \mathrm{~min}$, the samples were centrifuged at $1000 \mathrm{~g}$ and the supernatants frozen in liquid nitrogen until further investigation.

\section{Storage together with seminal plasma}

Freshly-collected semen (spermatocrit 35-45\%) was stored at $4^{\circ} \mathrm{C}$ for $160 \mathrm{~min}$. Immediately after collection and a storage period of $150 \mathrm{~min}$, spermatozoa were separated from the seminal fluid and washed twice in the motility-inhibiting solution. Spermatozoal metabolism was inactivated as described. To determine the lipid and sugar levels in the seminal fluid, it was centrifuged a second time for $5 \mathrm{~min}$ at $350 \mathrm{~g}$ and the supernatants were placed in boiling water for $10 \mathrm{~min}$ to terminate possible enzyme activity. All samples were stored in liquid nitrogen.

\section{Incubation of spermatozoa in artificial physiological saline solution}

Spermatozoa separated from the seminal fluid were incubated in the aforementioned physiological saline solution for $36 \mathrm{~h}$ at $4^{\circ} \mathrm{C}$. After periods of $0,2,4,12,24$ and $36 \mathrm{~h}$ the suspensions were mixed thoroughly and samples taken. The metabolism was inactivated as described. For control 2 semen samples were heat-inactivated at $80^{\circ} \mathrm{C}$ for $5 \mathrm{~min}$ and incubated in the same manner as the other samples. Throughout all incubation experiments spermatozoal vitality was determined by their motility. Transmission electron microscopy (TEM) was used to determine possible morphological alterations.

\section{Assay procedure}

Metabolites were determined by enzymatic assays in which the oxidation of NAD or NADP was measured by UV-spectrophotometry at 339 $\mathrm{nm}$. The amount of tissue extract was adjusted to fall within the linear range of the assay and 
the minimal sensitivity of the performed assays was $2.5 \mu \mathrm{M}$.

Glucose was determined with hexokinase glucose-6-phosphate dehydrogenase according to Kunst et al (Bergmeyer, 1985). Fructose was measured with phosphoglucose isomerase, hexokinase and glucose-6-phosphate dehydrogenase, sucrose with invertase, hexokinase and glucose-6-phosphate dehydrogenase. For both determinations the methods of Beutler (Bergmeyer, 1985) were used. Lactose and galactose determination also followed the method of Beutler (Bergmeyer, 1985) with $\beta$-galactosidase and galactose dehydrogenase. L-Lactate was measured according to the assay of Noll (Bergmeyer, 1985), hydroxybutyrate according to Williamson et al (1962). Phosphatidylcholine was determined with phospholipase $\mathrm{C}$ and choline kinase according to Schiefer and Beutler (Bergmeyer, 1985).

\section{Statistics}

Using the data of Christen et al (1987) the interval volume of spermatozoa was calculated as $0.16 \mu \mathrm{l} / 10^{7}$ cells. The significance of differences in metabolite mean values was tested by Student's $t$-test at a significance level of $p=0.05$.

\section{Fine structural investigations}

Samples a) of freshly collected spermatozoa; b) of spermatozoa after storage periods of $150 \mathrm{~min}$ in the seminal plasma; and c) of spermatozoa incubated for 24 or $36 \mathrm{~h}$ in the physiological saline solution were fixed in an unbuffered mixture of paraformaldehyde, glutaraldehyde and osmium tetroxide (Lahnsteiner and Patzner, 1991). They were dehydrated in an ethanol series and embedded in Epon 812. One hundred spermatozoa from each sample were examined under a Philips electron microscope EM 300.

\section{RESULTS}

\section{Motility}

In all cases spermatozoal semen samples diluted in the motility-inhibiting solution were immotile. By diluting them at a ratio of $1: 15$ with motility-activating solution a uniform motility $(80 \pm 10 \%)$ was initiated, which persisted for $45 \mathrm{~s}\left(4^{\circ} \mathrm{C}\right)$. During the first $25 \mathrm{~s}$ spermatozoa had a high linear motility. In the motility interval of 25 to $35 \mathrm{~s}$ spermatozoa mainly exhibited a rotary motion and after that only local motility was observed. When spermatozoa were centrifuged after initiation of motility and resuspended in the motility-inhibiting physiological saline solution after $\approx 360$ min, motility could again be reinitiated.

When spermatozoa were stored with the seminal plasma the motility rate decreased from $80 \pm 10 \%$ at the onset of incubation to $10 \pm 5 \%$ after 160 min incubation. When spermatozoa were incubated in the physiological saline solution, full motility could be initiated up to a storage period of $16 \mathrm{~h}$. Thereafter the motility rates decreased to $30 \pm 10 \%$ at $36 \mathrm{~h}$ of incubation.

\section{Fine structure}

In freshly collected rainbow trout semen $95 \%$ of the spermatozoa had an intact morphology (fig $1 \mathrm{~A}$ ). In the remaining 5\% the plasmalemma and the nuclear envelope showed signs of swelling and an abundance of vacuoles were found in the cytoplasm (fig 1B). In spermatozoa incubated in the seminal plasma for $150 \mathrm{~min}$ no fine structural changes in comparison to freshly collected spermatozoa were found. Also in spermatozoa diluted in the physiological saline solution, no fine structural changes could be observed up to incubation periods of $16 \mathrm{~h}$. After an incubation period of $36 \mathrm{~h}$, only $50 \%$ of spermatozoa had a similar intact structure to freshly collected spermatozoa. The remaining spermatozoa showed structural changes, as numerous vacuoles originated in the cytoplasm and the nuclear envelope was lifted off the chromatin material in some places (fig 1C). 

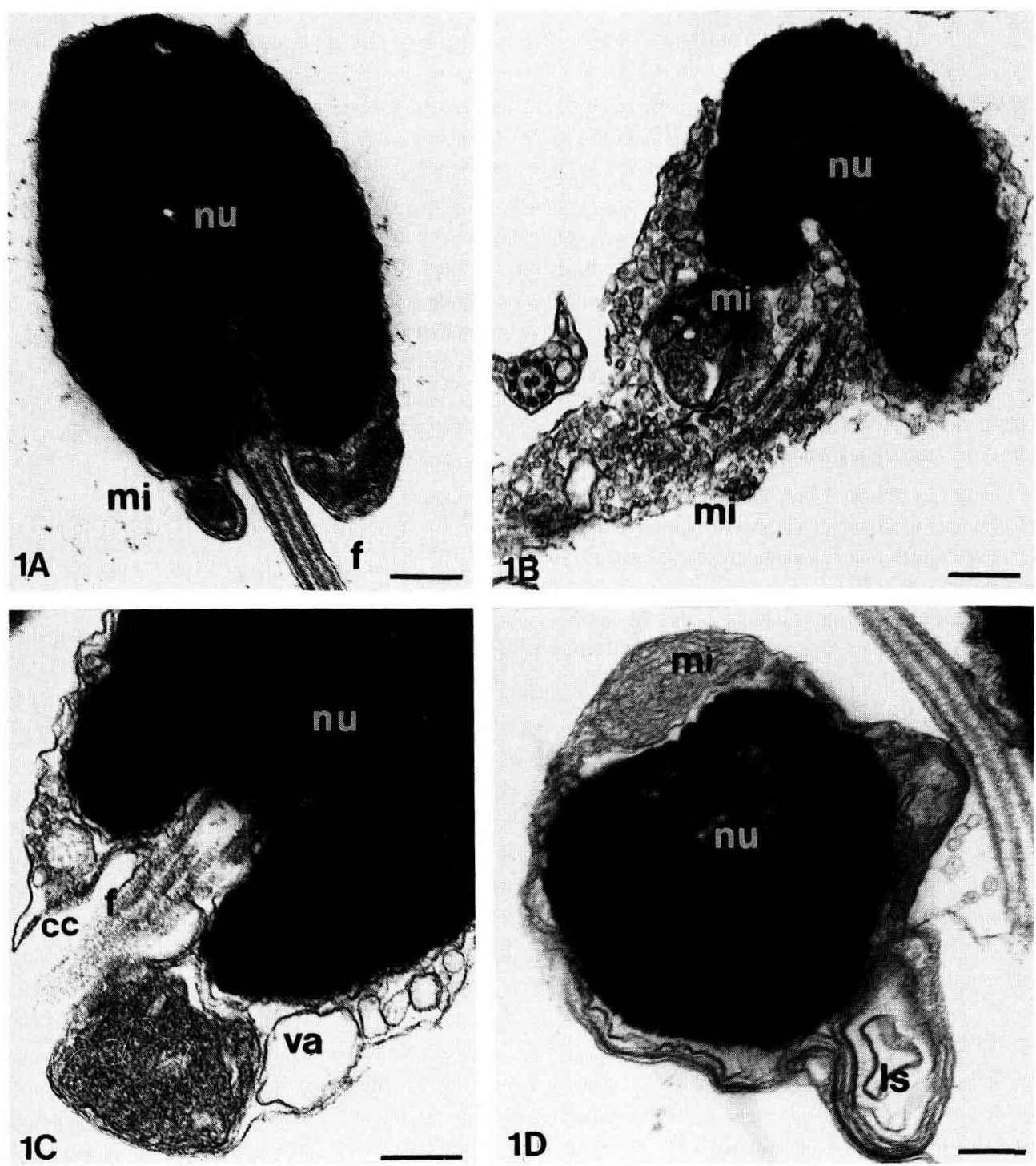

Figs 1A-D. Fine structural characteristics of spermatozoa of the rainbow trout during the incubation experiments. cc: cytoplasmic channel; f: flagellum; Is: lamellar structures; mi: mitochondrium; nu: nucleus; va: vacuole. 1A. Storage for $160 \mathrm{~min}$ with the seminal plasma. bar $=0.3 \mu \mathrm{m}$. 1B. Damaged spermatozoon immediately after collection. bar $=0.3 \mu \mathrm{m}$. 1C. Alterations after $24-\mathrm{h}$ incubation in physiological saline solution, head region. bar $=0.1 \mu \mathrm{m}$. 1D. Formation of lamellar structures after $24-\mathrm{h}$ incubation in physiological saline solution. bar $=0.2 \mu \mathrm{m}$. 
Furthermore, the formation of lamellar structures was observed in the spermatozoa, which might indicate the occurrence of degenerative processes (fig 1D).

\section{Enzyme activity}

Rainbow trout spermatozoa have lipase, phospholipase, hydroxybutyrate dehydrogenase, lactate dehydrogenase, pyruvate kinase and fatty acid synthase activity (table I). No $\alpha$ - and $\beta$-glucosidase activity could be determined.

\section{Metabolite levels of spermatozoa during motility (table II)}

Rainbow trout spermatozoa contain intracellular glucose, fructose and triglycerides. Neither galactose, sucrose nor lactose were found. During motility glucose levels decreased by $\approx 25 \%$ during the first 30 s of motility (table II; fig 2A). During further motility and during the regeneration phase they showed no further changes. Lactate levels decreased by $\approx 10 \%$ during the first $30 \mathrm{~s}$ of motility and then remained con- stant. Triglyceride levels showed no significant changes during motility. In the 5-min to $20-\mathrm{min}$ period after initiation of motility, they decreased by $\approx 50 \%$ (table II; fig $2 \mathrm{~B}$ ). No significant changes were found in fructose $\left(0.92 \pm 0.46 \mu \mathrm{mol} / 10^{13}\right.$ spermatozoa (spz) and hydroxybutyrate levels (4.69 \pm $1.35 \mu \mathrm{mol} / 10^{13} \mathrm{spz}$ ) during motility and during the regeneration phase.

In the presence of potassium cyanide, glucose levels decreased by $\approx 15 \%$ during the first $30 \mathrm{~s}$ of motility and then remained constant (table II; fig 2A). Lactate levels increased by $\approx 40 \%$ during the first $30 \mathrm{~s}$ of motility and then showed no further changes. Triglyceride levels did not alter during the regeneration phase (table II; fig 2B).

\section{Metabolite levels of spermatozoa during storage in physiological saline solution and in seminal plasma}

\section{Physiological saline solution (table III)}

The triglyceride levels in 18 batches increased by $\approx 15 \%$ during the first $2 \mathrm{~h}$ of incubation. They then remained constant until an incubation period of $4 \mathrm{~h}$. In the

Table I. Enzymatic activities ( $\mu \mathrm{M}$ substrate/min $/ 10^{13}$ spermatozoa) in rainbow trout spermatozoa (mean $\pm \mathrm{SD})$.

\begin{tabular}{lrr}
\hline Enzyme & Activity & $n$ \\
\hline & & \\
\hline & $70 \pm 33$ & 12 \\
Phose & $21 \pm 7$ & 12 \\
Lactate dehydrogenase & $799 \pm 91$ & 12 \\
Hydroxybutyrate dehydrogenase & $213 \pm 72$ & 5 \\
Glucose-6-phosphate dehydrogenase & $24 \pm 10$ & 5 \\
Pyruvate kinase & $14 \pm 3$ & 12 \\
Fatty acid synthase & $15 \pm 11$ a & 15
\end{tabular}

\footnotetext{
${ }_{\mu \mathrm{M}}$ malonyl-CoA dependent oxidation of $\mathrm{NADPH} / \mathrm{min}$.
} 
Table II. Changes in metabolite levels ( $\mu \mathrm{mol} / 10^{13}$ spermatozoa) of rainbow trout spermatozoa during motility (mean $\pm S D, n=15$ ).

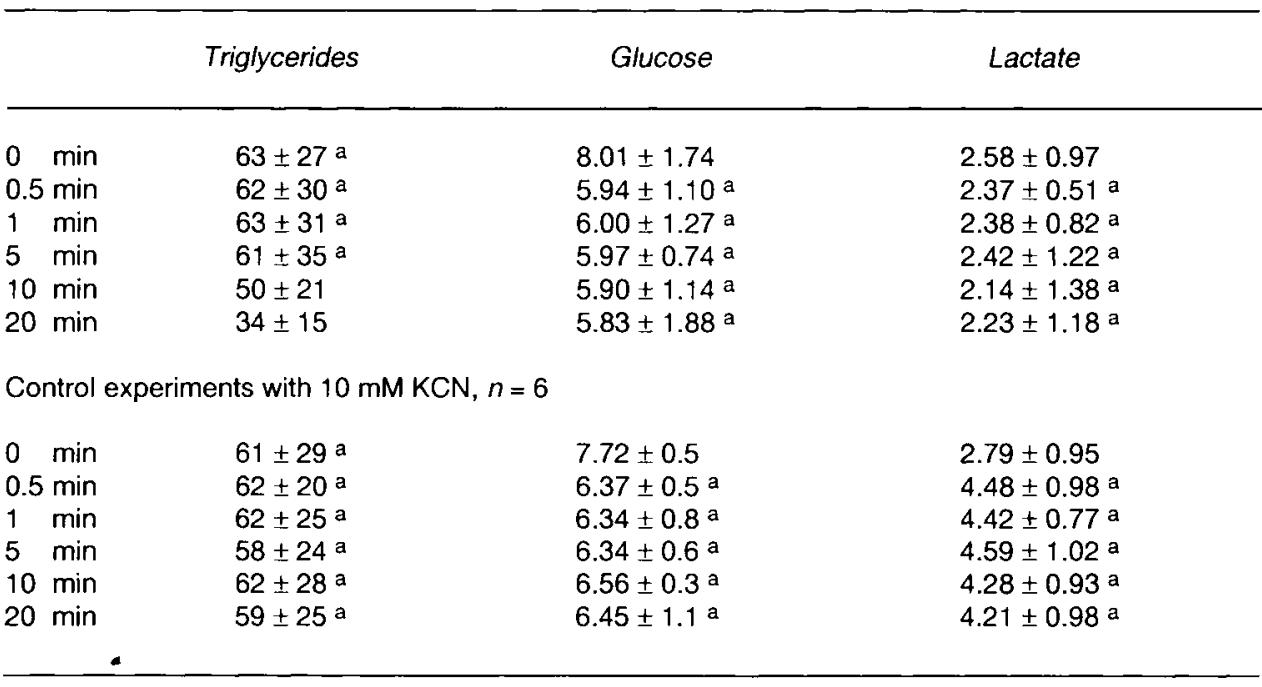

a Means subscripted by the same letter are not significantly different.

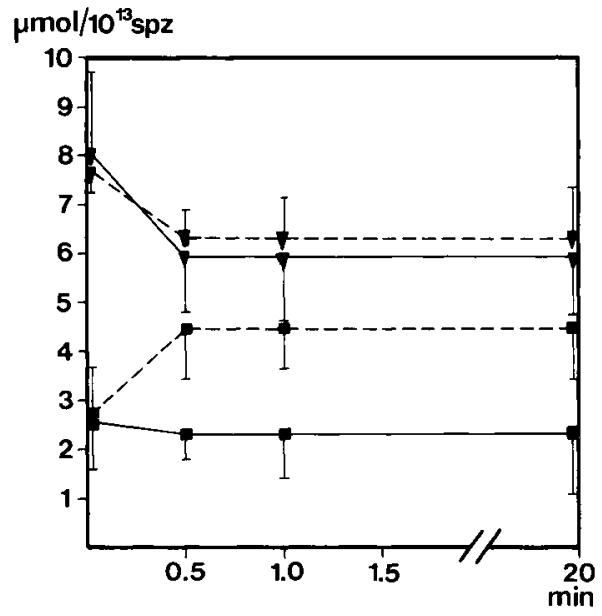

2A

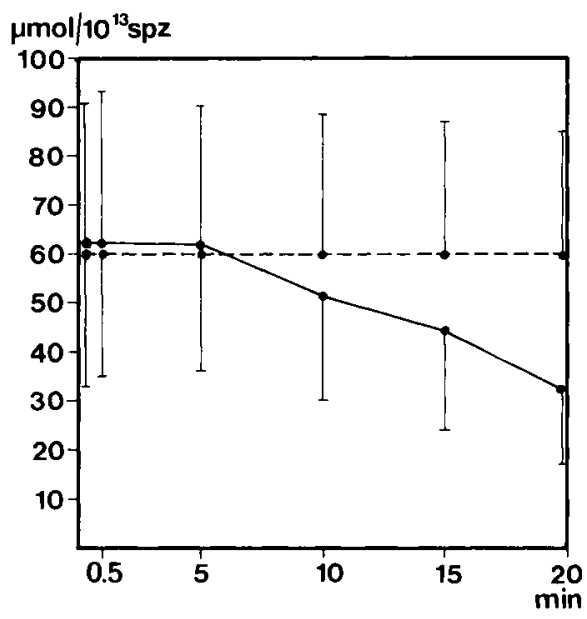

$2 \mathbf{B}$

Fig 2. Changes in spermatozoal intracellular metabolite levels ( $\mu \mathrm{mol} / 10^{13} \mathrm{spz}$ [spermatozoa]) of the rainbow trout when motile. Broken lines show control experiments with $10 \mathrm{mM} \mathrm{KCN}$. Vertical bars represent SD. 2A. $\mathbf{\nabla}$ : glucose levels; $\boldsymbol{\square}$ : lactate levels; 2B. $\bullet$ : triglyceride levels. 
Table III. Changes in metabolite levels ( $\mu \mathrm{mol} / 10^{13}$ spermatozoa) of rainbow trout spermatozoa during incubation in physiological saline solution (mean \pm SD).

\begin{tabular}{rllll}
\hline & \multicolumn{2}{c}{ Triglycerides } & Glucose & Lactate \\
\hline & & & \\
& & & & \\
$0 \mathrm{~h}$ & $69 \pm 22$ & $75 \pm 11$ & $7.07 \pm 1.81$ & $n=30$ \\
$2 \mathrm{~h}$ & $62 \pm 24$ & $89 \pm 20^{\mathrm{a}}$ & $6.41 \pm 1.59$ & $2.81 \pm 0.88$ \\
$4 \mathrm{~h}$ & $51 \pm 20$ & $87 \pm 24^{\mathrm{a}}$ & $6.00 \pm 1.65$ & $2.19 \pm 0.44 \mathrm{a}$ \\
$12 \mathrm{~h}$ & $41 \pm 20$ & $80 \pm 25$ & $5.83 \pm 1.06 \mathrm{a}$ & $2.23 \pm 0.77^{\mathrm{a}}$ \\
$24 \mathrm{~h}$ & $28 \pm 10$ & $70 \pm 19$ & $5.70 \pm 1.21^{\mathrm{a}}$ & $2.16 \pm 0.80^{\mathrm{a}}$ \\
$36 \mathrm{~h}$ & $23 \pm 7$ & $64 \pm 20$ & $5.91 \pm 1.28 \mathrm{a}$ & $2.18 \pm 0.92^{\mathrm{a}}$ \\
& & & & \\
\hline
\end{tabular}

a Means with the same letter in superscript are not significantly different from each other ; A: batches catabolizing triglycerides; B: batches synthesizing triglycerides; utilization rate of glucose and lacate was similar in all batches.

incubation interval from $4 \mathrm{~h}$ to $36 \mathrm{~h}$, they decreased by $\approx 30 \%$ (table III; fig 3 ). In 12 batches the triglyceride levels decreased during the whole incubation period by $\approx 65 \%$ (table III, fig 3). In all investigated batches the rate of glucose utilization was similar. Glucose levels decreased by $\approx 20 \%$ during the first $12 \mathrm{~h}$ incubation. After that no further changes were observed (table III; fig 3). Lactate levels decreased by $\approx 10 \%$ at the beginning of incubation, after which no further change occurred. Hydroxybutyrate levels $(3.54 \pm 1.67 \mu \mathrm{mol} /$ $10^{13} \mathrm{spz}$ ) remained constant. In control experiments with heat-inactivated spermatozoa, metabolite levels remained unchanged during the whole incubation period (triglyceride levels: $53.0 \pm 19.7 \mu \mathrm{mol} /$ $10^{13} \mathrm{spz}$; glucose: $6.01 \pm 2.16 \mu \mathrm{mol} / 10^{13}$ spz; lactate: $1.90 \pm 0.91 \mu \mathrm{mol} / 10^{13} \mathrm{spz}$ ).

\section{Seminal plasma}

The triglyceride levels of seminal fluid in 13 batches increased from $3.71 \pm 0.46 \mathrm{mM}$ at the beginning of incubation to $3.94 \pm$ $0.55 \mathrm{mM}$ (by $\approx 5 \%$ ) after $150 \mathrm{~min}$ incubation. In the other 8 batches the seminal fluid triglyceride levels decreased from $3.85 \pm 0.47 \mathrm{mM}$ to $3.49 \pm 0.72 \mathrm{mM}$ (by $10 \%$ ) during the incubation period. Phosphatidylcholine levels of the seminal fluid remained constant at $4.08 \pm 2.13 \mathrm{mg} / 100$ $\mathrm{ml}(n=10)$. Also seminal plasma glucose $(0.39 \pm 0.14 \mathrm{mM}, n=21)$ and fructose (0.30 $\pm 0.14 \mathrm{mM}, n=21$ ) levels remained constant during incubation.

Intracellular glucose levels of spermatozoa in all batches decreased from $14.74 \pm$ $1.76 \mu \mathrm{mol} / 10^{13} \mathrm{spz}$ to $10.52 \pm 3.23 \mu \mathrm{mol} /$ $10^{13} \mathrm{spz}(n=13$ ) (by $\approx 30 \%$ ) during the 150 -min storage period. Lactate levels of spermatozoa decreased from $3.01 \pm 1.38$ $\mu \mathrm{mol} / 1013 \mathrm{spz}$ to $2.89 \pm 0.98 \mu \mathrm{mol} / 10^{13}$ $\mathrm{spz}(n=13)$ (by $\approx 8 \%$ ), intracellular triglycerides $\left(128.00 \pm 31.00 \mu \mathrm{mol} / 10^{13} \mathrm{spz}, n=\right.$ 13), fructose (1.32 $\pm 0.72 \mu \mathrm{mol} / 10^{13} \mathrm{spz}, n$ $=13)$ and hydroxybutyrate (5.86 \pm 2.14 $\mu \mathrm{mol} / 10^{13} \mathrm{spz}, n=13$ ) levels remained unchanged. 


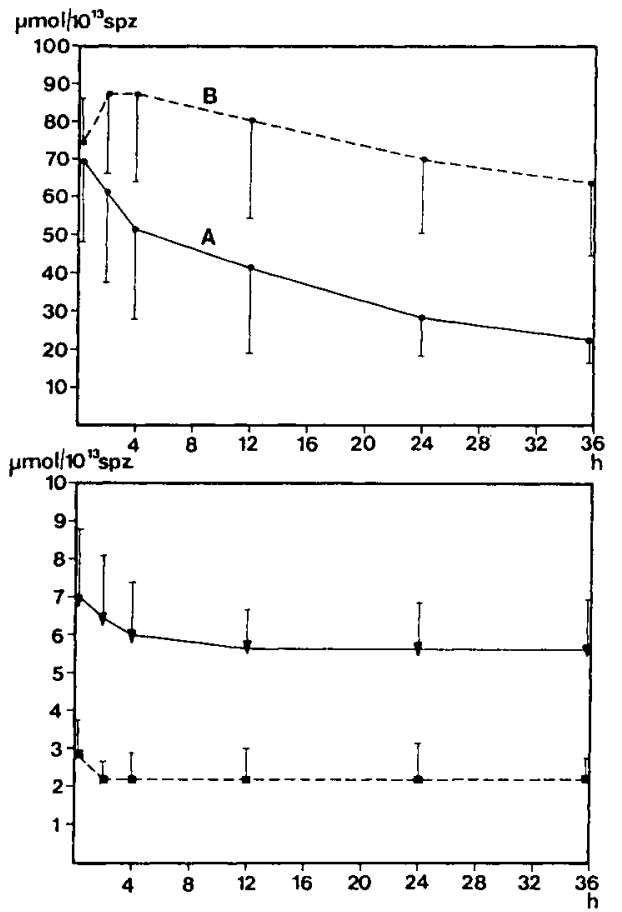

Fig 3. Changes in intracellular metabolite levels ( $\mu \mathrm{mol} / 10^{13} \mathrm{spz}$ [spermatozoa]) of rainbow trout spermatozoa during incubation in a physiological saline solution. Vertical bars represent SD. Upper diagram: : triglyceride levels. In batches $A$ triglycerides were catabolized during the whole incubation period; in batches B triglycerides were synthesized at the onset of incubation. Lower diagram: $\boldsymbol{\nabla}$ : glucose levels; $\mathbf{\square}$ : lactate levels. The glycolysis rate was similar in all batches.

\section{DISCUSSION}

Lactate dehydrogenase, pyruvate kinase, lipase, phospholipase and hydroxybutyrate dehydrogenase activity in Oncorhynchus mykiss spermatozoa demonstrate their enzymatic capacity for glycolysis as well as for catabolism of triglycerides and phospholipids. Fatty acid synthase and glucose 6-phosphate dehydrogenase enable them to synthesize fatty acids and triglycerides. The spermatozoa are not able to use poly- saccharides as energy reserves: glycogen deposits (Billard, 1986) and glucosidase activity are lacking and also the seminal fluid does not contain polysaccharides (Lahnsteiner et al, 1992b). Rainbow trout spermatozoa utilize triglycerides and glucose as primary energy resources. Fructose, which is present in small traces in the seminal fluid as well as in the spermatozoa, is not utilized. This might be due to a competitive inhibition of hexokinase by glucose.

\section{Energy resources during motility}

When spermatozoa are shed into the water the limiting factors in sperm motility are osmotic damage and a decrease in ATP (Billard, 1978; Christen et al, 1987). Avoiding an osmotic shock by initiating motility in a physiological saline solution, motility is terminated due to the loss of ATP which is regenerated after motility has ended (regeneration phase) (Christen et al, 1987). Therefore the utilization of readily available ATP is the most important energy source for flagellar beating. However, the present study demonstrates that spermatozoa do not exclusively use accumulated ATP. Glycolysis occurs during the first $30 \mathrm{~s}$ of motility characterized by highest flagellar beat frequencies (Billard and Cosson, 1992) to regenerate ATP levels. As the ATP levels cannot be maintained (Christen et al, 1987) the ATP utilization rate is higher than its synthesis by glycolysis, suggesting that only a small amount of glucose can be consumed. The regeneration phase is characterized by a shift from glycolysis to triglyceride utilization as glycolysis is terminated and only utilization of triglycerides occurs. By contrast, during imotile storage of spermatozoa, glycolysis and triglyceride catabolism can occur simultaneously (see below). The parameters regulating these energy delivering pathways are still not known. 
When cytochrome oxidase is blocked by cyanide, glycolysis occurs anaerobically as lactate levels increase significantly. Under this condition, however, the rate of glucose utilization is reduced by $\approx 15 \%$. This correlates with the findings of Christen et al (1987), that the decrease in ATP is greater when blocking the respiratory compartment of spermatozoa. With the addition of cyanide the regeneration phase is completely suppressed as neither triglyceride catabolism nor glycolysis occurs. This correlates with the results of Christen et al (1987).

In the spermatozoa of the cyprinid fish Leuciscus cephalus glycolysis also occurs during motility. In contrast to the representatives of the Salmonidae family, in this species belonging to the Cyprinidae family spermatozoa lack lipase activity and are only capable of using monosaccharides as energy reserves (Lahnsteiner et al, 1992a). In mammals spermatozoal motility persists up to several hours and fructose is the most important energy substrate for flagellar beating (Guraya, 1987).

\section{Energy resources of immotile spermatozoa during storage together with the seminal plasma or in a physiological saline solution}

During their immotile incubation with seminal fluid or in physiological saline solution triglyceride catabolism as well as glycolysis occurs in rainbow trout spermatozoa: at the beginning of incubation in $\approx 60 \%$ of the investigated samples spermatozoa synthesize triglycerides and glycolysis occurs for providing energy. Triglyceride synthesis of spermatozoa of the rainbow trout is shown by the occurrence of a fatty acid synthase and glucose-6-phosphate dehydrogenase activity and by the significant increase in triglyceride levels and has also been described by Terner and Korsh (1963b). In the remaining $\approx 40 \%$ of the batches, glycolysis as well as catabolism of triglycerides is used for providing energy. This simultaneous utilization of glucose and triglycerides indicates a higher energy consumption, the physiological reasons of which are not known. No significant differences could be found in these batches compared to the others either in motility rates or in the levels of intracellular glucose and triglycerides or in enzyme activity (Lahnsteiner et al, unpublished observations). The sperm duct of the rainbow trout itself produces high amounts of lipids and the seminal fluid also contains triglycerides (Lahnsteiner et al, 1992b). Thus it might be suggested that spermatozoa mainly use lipids as energy reserves while remaining in the sperm ducts and that triglyceride synthesis might be a response to distinct physiological changes during artificial storage. After $\approx 12 \mathrm{~h}$ incubation in physiological saline solution, glycolysis stops and triglyceride catabolism is the only means of providing energy. However, the spermatozoa still contain glucose and their enzyme activity does not significantly differ from that of freshly incubated spermatozoa (Lahnsteiner et al, unpublished observations). Lactate levels decrease at the beginning of incubation which may be due to anaerobic conditions during manipulation (eg centrifugation) before the setting up of the experiments. During incubation they remain unchanged, indicating the aerobic occurrence of glycolysis.

In rainbow trout spermatozoa motility could be initiated only for $\approx 2 \mathrm{~h}$ when spermatozoa were stored with the seminal plasma, although no morphological alterations took place during this period. By contrast, motility could be initiated for up to 36 $h$ when spermatozoa were incubated in physiological saline solution. During this incubation period lamellar bodies originated in the spermatozoa, indicating cell death and the onset of degenerative processes. The reasons for the short-term vitality of 
spermatozoa incubated with the seminal fluid are not exactly known. Proteolytic activity of the seminal fluid (Lahnsteiner et al, 1992b) may limit the lifespan of the spermatozoa. Further, in a thin layer and supplied with oxygen spermatozoa can be stored for $>1$ wk with the seminal fluid, also indicating oxygen as a limiting factor in sperm vitality (Billard, 1981; Stoss and Holtz, 1983). As lactate levels did not increase during incubation experiments and also oxygen-consuming triglyceride catabolism occurred, the decrease in oxygen seems to play no role under the present experimental conditions.

\section{ACKNOWLEDGMENTS}

Supported by the Austrian Bundesministerium für Land- und Forstwirtschaft (project No L682/ 91) and the Bundesanstalt für Fortpflanzung und Besamung von Haustieren in Wels, Austria. Material was provided from the fishery farms in Kreuztein (Mondsee), from Mr Achleitner (Mattighofen) and Mr Karlhuber (Uttendorf).

\section{REFERENCES}

Bergmeyer HU (1985) Methods of Enzymatic Analysis. VCH Verlagsgesellschaft, Weinheim

Billard R (1978) Changes in structure and fertilizing ability of marine and freshwater fish spermatozoa diluted in media of various salinities. Aquaculture 14, 187-198

Billard R (1981) Short-term preservation of sperm under oxygen atmosphere in rainbow trout (Salmo gairdneri). Aquaculture 23, 287-293

Billard R (1986) Spermatogenesis and spermatology of some teleost fish species. Reprod Nutr Dev 26, 877-920

Billard R, Cosson MP (1992) Some problems related to the assessment of sperm motility in freshwater fish. J Exp Zool 261, 122-131

Christen R, Gatti JL, Billard R (1987) Trout sperm motility. The transient movement of trout sperm is related to changes in concentration of ATP following the activation of the flagellar movement. Eur J Biochem 166, 667671

Gardiner DM (1978) Utilization of extracellular glucose by spermatozoa of two viviparous fishes. Comp Biochem Physiol 59, 165-168

Guraya SS (1987) Biology of Spermatogenesis and Spermatozoa in Mammals. Springer Verlag, Berlin

Lahnsteiner F, Patzner RA (1991) A new method for electron microscopical fixation of fish spermatozoa. Aquaculture 97, 301-304

Lahnsteiner F, Patzner RA, Weismann T (1992a) Monosaccharides as energy resources during motility of spermatozoa in Leuciuscus cephalus (Cyprinidae, Teleostei). Fish Physiol Biochem 10, 283-289

Lahnsteiner F, Patzner RA, Weismann T (1992b) The spermatic duct of salmonid fishes (Salmonidae, Teleostei): morphology, histochemistry and composition of the secretion. J Fish Biol 42, 79-93

Lowenstein JM (1981) Methods in Enzymology: Lipids. Academic Press, New York, vol 71, 72

Minassian ES, Terner C (1966) Biosynthesis of lipids by human and fish spermatozoa. $A m ~ J$ Physiol 210, 615-618

Mounib MS (1967) Metabolism of pyruvate, acetate and glyoxylate by fish sperm. Comp Biochem Physiol 20, 987-992

Stoss $J$ (1983) Fish gamete preservation and spermatozoon physiology. In: Fish Physiology (Hoar WS, Randall DJ, Donaldson EM, eds) Academic Press, NY, vol 9, 305-350

Stoss J, Holtz W (1983) Successful storage of chilled rainbow trout (Salmo gairdneri) spermatozoa for up to 34 days. Aquaculture 31 , 269-274

Terner C, Korsh G (1963a) The oxidative metabolism of pyruvate, acetate and glucose in isolated fish spermatozoa. J Cell Comp Physiol $62,243-249$

Terner C, Korsh G (1963b) The biosynthesis of fatty acids, of glycerides and phosphatides by isolated spermatozoa of the rainbow trout. J Cell Comp Physiol 62, 251-255

Williamson DH, Mellandy J, Krebs HA (1962) Enzymatic determination of $\beta$-hydroxybutyric acid and acetoacetic acid in blood. Biochem $J 82,90$ 
Billard R (1981) Short-term preservation of sperm under oxygen atmosphere in rainbow trout (Saimo gairdneri). Aquaculture 23, 287-293

Billard $R$ (1986) Spermatogenesis and spermatology of some teleost fish species. Reprod Nutr Dev 26, 877-920

Billard R, Cosson MP (1992) Some problems related to the assessment of sperm motility in treshwater fish. J Exp Zool 261, 122-131

Christen R, Gattj JL, Billard R (1987) Trout sperm motility. The transient movement of trout sperm is related to changes in concentration of ATP following the activation of the flagellar movement. Eur J Biochem 166. 667-671

Gardiner DM (1978) Utilization of extracellular glucose by spermatozoa of two viviparous fishes. Comp Biochem Physio/ 59, 165-168

Guraya SS (1987) Biology of Spermatogenesis and Spermatozoa in Mammals. Springer Verlag. Berlin

Lahnsteiner F, Patzner RA (1991) A new method for electron microscopical fixation of fish spermatozoa. Aquaculture 97, 301-304

Lahnsteiner F. Patzner RA, Weismann T (1992a) Monosaccharides as energy resources during motility of spermatozoa in Leuciuscus cephalus (Cyprinidae, Teleostei). Fish Physiol Biochem 10, 283-289

Lahnsteiner $F$, Patzner RA, Weismann $T$ (1992b) The spermatic duct of salmonid fish- es (Salmonidae, Teloostei): morphology, histochemistry and composition of the secretion. $J$ Fish Biol 42, 79-93

Lowenstein JM (1981) Methods in Enzymology: Lipids. Academic Press, New York, vol 71, 72

Minassian ES, Terner C (1966) Biosynthesis of lipids by human and fish spermatozoa. $A m J$ Physiol 210, 615-618

Mounib MS (1967) Metabolism of pyruvate, acetate and glyoxylate by fish sperm. Comp Biochem Physiol 20, 987-992

Stoss $J$ (1983) Fish gamete preservation and spermatozoon physiology. In: Fish Physiology (Hoar WS, Randall DJ, Donaldson EM, eds) Academic Press, NY, vol 9, 305-350

Stoss J, Holtz W (1983) Successful storage of chilled rainbow trout (Salmo gairdneri) spermatozoa for up to 34 days. Aquaculture 31, 269-274

Terner C, Korsh G (1963a) The oxidative metabolism of pyruvate, acetate and glucose in isolated fish spermatozoa. J Cell Comp Physiol 62, 243-249

Terner C, Korsh G (1963b) The biosynthesis of fatty acids, of glycerides and phosphatides by isolated spermatozoa of the rainbow trout. J Cell Comp Physiol 62, 251-255

Williamson DH, Mellandy J, Krebs HA (1962) Enzymatic determination of $\beta$-hydroxybutyric acid and acetoacetic acid in blood. Biochem $J 82,90$ 